\title{
Mewujudkan Desa Anti Politik Uang pada Pemilu 2019 di Desa Temon Kulon Kabupaten Kulon Progo
}

\author{
Muhammad Eko Atmojo', Vindhi Putri Pratiwi ${ }^{2}$ \\ 1,2Ilmu Pemerintahan, Fakultas Ilmu Sosial dan Ilmu Politik \\ Universitas Muhammadiyah Yogyakarta \\ e-mail: atmojoeko91@gmail.com
}

\begin{abstract}
Abstrak
Politik uang merupakan salah satu fenomena yang banyak terjadi pada saat pelaksanaan pemilihan umum, pemilihan kepala daerah maupun pemilihan kepala desa. Praktik politik uang sudah banyak terjadi dikalangan masyarakat Indonesia hal ini dikarenakan minimnya pendidikan politik terhadap masyarakat. Dimana jika dilihat praktik politik uang ini mempunyai konsekuensi dampak yang sangat panjang dan serius. Maka dampak dari praktik politik uang adalah biaya politik mahal, masyarakat bukan menjadi prioritas serta akan menimbulkan korupsi diberbagai sector. Oleh karena itu beberapa desa di Daerah Istimewa Yogyakarta melakukan perlawanan politik uang melalui gerakan Desa Anti Politik Uang (DAPU). Salah satunya di Desa Temon Kulon Kecamatan Temon Kabupaten Kulon Progo. Adapun kegaitan yang dilakukan selama pengabdian adalah sosialisasi tata bahaya politik uang dan penggunaan surat suara, selain itu juga dilakukan pembuatan spanduk dan pojok aduan sebagai symbol perlawanan politik uang.
\end{abstract}

Kata Kunci: Politik Uang, DAPU, Pemilu dan Sosialisasi

\begin{abstract}
Money politics is one of the phenomena that occur a lot during the implementation of elections, regional head elections and village head elections. The practice of money politics has occurred a lot among the people of Indonesia this is due to the lack of political education to the community. Where if viewed the political practice of money has a very long and serious impact consequences. So the impact of the political practice of money is a costly political cost, society is not a priority and will cause corruption in various sectors. Therefore, some villages in the Special Region of Yogyakarta conducted money political resistance through the Anti-Money Politics Village (DAPU) movement. One of them is in Temon Kulon Village, Temon District, Kulon Progo Regency. The noise carried out during the service is the socialization of the political dangers of money and the use of ballots, in addition to the creation of banners and corner complaints as a symbol of money political resistance.
\end{abstract}

Keywords: Money politics, the Anti-Money Politics Village (DAPU), Election and Sosialitation 


\section{Pendahuluan}

Pemilihan umum di Indonesia merupakan kegiatan yang dilakukan setiap 5 tahunan, selain itu pemilu juga disebut sebagai pesta demokrasi bagi masyarakat. Pelaksanaan pemilu di Indonesia tergolong ke beberapa kategori, diantaranya adalah pemilihan umum, dan pemilihan kepala daerah. Penerapan pemilu yang diadakan di Indonesia memakai asas langsung, universal, leluasa, rahasia serta adil (LUBERJURDIL). Berdasarkan pernyataan dari (Asmawi; Amiludin \& Sofwan, 2021) bahwa kelima asas yang dipakai dalam pemilihan umum mempunyai kedudukan yang sama dalam menghasilkan pejabat berintegritas tinggi. Dengan adanya asas tersebut masyarakat mempunyai kebebasan untuk melakukan pemilihan kepada calon yang dikehendaki dan sesuai dengan hati nuraninya.

Asas tersebut merupakan sebuah slogan untuk mendukung pelaksanaan pemilu yang bersih dan berintegritas, akan tetapi ralita yang terjadi di Indonesia banyak sekali praktik-praktik politik uang (money politics). Hal ini merupakan tantangan bagi penyelenggara pemilu di Indonesia, terutama untuk menghilangkan praktik-praktik politik uang pada saat pelaksanaan pemilu maupun pemilukada. Jika berbicara mengenai politik uang ada beberapa pengertia dari beberapa pakar, diantaranya adalah Dwipayana yang menyebutkan bahwa politik uang salah satu factor penyebab demokrasi bebiaya tinggi (Suprianto; Arsyad \& Tawulo, 2019). Selain itu Kumurotomo menyatakan bahwa politik uang hal yang jamak dalam pelaksanaan pemilu setelah reformasi (Suprianto; Arsyad \& Tawulo, 2019).

Fenomena politik uang memang susah untuk dihindari, mengingat hal ini merupakan sebuah kelaziman yang dilakukan pada pelaksanaan pemilu maupun pemilukada. Praktik-praktik politik uang selalu muncul setiap 5 tahun sekali, karena hal ini sudah menjadi bagian dari rutinitas bagi masyarakat Indonesia maupun bagi calon. Praktik ini memang tumbuh subur dikalangan masyarakat Indonesia, hal ini dikarenakan minimnya pendidikan politik kepada masyarakat. Meningkatnya praktik politik uang ini merupakan bentuk "penindasan" sebagai hubungan patron klien antara caleg dan calon pemilih (Abhipraya, Sadayi \& Putri, 2020). Selain itu menurut (Muhtadi, 2013) bahwa rendahnya party-ID juga berkontribusi terhadap maraknya politik uang dikalangan masyarakat. Sehingga banyak masyarakat yang beranggapa bahwa dengan adanya politik uang merupakan bagian dari penghasilan setiap 5 tahun sekali. Minimnya pendidikan politik mengakibatkan kepekaan masyarakat akan bahaya politik uang semakin berkurang, hal ini dikarenakan masyarakat menganggap bahwa proses politik uang merupakan bagian yang wajar dalam pelaksanaan demokrasi.

Jika berbicara mengenai akibat atau dampak dari politik uang sangatlah berbahaya, karena dampak tersebut akan dirasakan oleh masyarakat dalam jangak yang cukup lama. Dampak yang secara langsung tidak dirasakan oleh masyarakat ini dianggap 
sebagai bagian yang tidak ada, sehingga masyarakat menerima praktik-praktik politik uang. Fenomena praktik politik uang yang terjadi di Indonesia bukan hanya pembelian suara melalui pemberian uang, akan tetapi praktiknya sudah berubah ke beberapa hal seperti bantuan dalam bentuk kegiatan dan lain sebagainya. Maka dari itu dalam fenomena sosiologis dikatakan bahwa bantuan politis dipahami sebagai bentuk system pertukaran sosial yang biasa terjalin dalam realitas permainan politik, sebab interaksi politik ataupun kedekatan relasi resiprositas ialah bagian dari terciptanya system pertukaran sosial yang balance (Suprianto, Arsyad \& Tawulo, 2019).

Jika masyarakat menanggap bahwa praktik politik uang merupakan bagian dari pertukaran sosial maka hal ini menjadi sebuah bencana bagi demokrasi Indonesia. Anggapan-anggapan tersebut akan disalahgunakan oleh pemangku kepentingan dalam mehalalkan semua cara untuk mewujudkan keinginnanya. Salah satu akibat dari politik uang adalah tingginya biaya politik sehingga mengakibatkan peluangpeluang untuk melakukan korupsi. Menurut Aspinall dan Sukmajati bahwa politik uang sebagai the mother of corruption adalah hal yang sering terjadi dan menjadi persoalan utama di Indonesia (Aspinall, Sukmajati, 2015). Selain itu Menurutnya Pahlevi bahwa politik uang menjadi corong utama dalam menghasilkan seorang pemimpin yang pro terhadap kepentingan individu serta kelompok (Pahlevi \& Amrurobi, 2020).

Jika dilihat dampak politik uang selain korupsi adalah terciptanya biaya politik yang tinggi, terciptanya pemimpin yang tidak pro rakyat, serta terciptanya persiangan demokrasi yang tidak sehat. Hal semacam ini akan merusak proses demokrasi serta melahirkan pemimpin yang korup. Biaya politik yang tinggi jelas akan melahirkan pemimpin yang mementingkan kepentingannya, terutama dalam hal pengembalian modal untuk mengikuti pemilu. Jika seorang pemimpin yang terpilih sudah mementingkan kepentingan diri sendiri dan kelompok maka pasti akan menimbulkan praktik-praktik korupsi di berbagai sector. Berdasarkan hasil penelitian dari (Sjafrina, 2019) bahwa terdapat tiga belas kasus korupsi politik yang ditangani KPK yang beririsan dengan biaya pemenangan pemilu, seperti jual beli tiket pencalonan dan jual beli suara. Tentu hal ini memperlihatkan bahwa dampak politik uang memang sangat luar biasa untuk merusak system demokrasi yang sudah tebentuk. Selain itu menurut (Satria, 2019) bahwa politik uang tidak senada dengan tujuan penyelenggaraan pemilu, diantaranya adalah: pertama, memperkuat system ketatanegaraan yang demokratis; kedua, mewujudkan pemilu yang adil dan berintegritas; ketiga, mewujudkan pemilu yang efektif dan efisien. Sedangkan menurut (Fitriyah, 2012) bahwa pembiaran politik uang tidak hanya mempunyai dampak atau implikasi dalam melahirkan politisi korup namun juga berakibat pada tercederainya pemilu yang demokratis. 
Banyaknya praktik dan dampak politik uang yang merugikan masyarakat maka perlu direspon dengan trobosan baru dalam melawan praktik politik uang tersebut. Selama ini bentuk praktik politik uang sangat sulit sekali untuk dibuktikan karena menurut (Ananingsih, 2016) bahwa praktik politik uang muncul karena adanya kendala yang dihadapi oleh Bawaslu dalam melakukan penanganan diantaranya norma saknsi pidana, keterbatasan Bawaslu dan perbedaan persepsi di Sentra Gakkumdu. Maka dari itu bentuk perlawanan politik uang yang bisa dilakukan adalah dengan memberikan pendidikan politik kepada masyarakat. Hal ini dirasa sangat penting karena selama ini masyarakat minim sekali mendapatkan pendidikan politik. Pemberian pendidikan politik dilakukan agar masyarakat memiliki pemahaman terhadap politik yang baik dan sanggup berpartisipasi secara maksimal (Marsudi \& Sunarso, 2019). Salah satu cara pemberian pendidikan politik yang bisa dilakukan adalah dengan membentuk Desa Anti Politik Uang (DAPU). Desa anti politik uang sendiri pada saat ini sudah banyak dibentuk oleh masyarakat khususnya di Daerah Istimewa Yogyakarta. Gerakan ini merupakan bentuk perlawanan masyarakat terhadap praktik politik uang.

Gerakan perlawanan ini muncul dikarenakan banyaknya praktik politik uang yang terjadi setiap pelaksanaan pemilu maupun pemilukada serta pilkades. Berdasarkan pernyataan dari Purnamasari bahwa berdasarkan survey yang dilakukan oleh Lembaga Ilmu Pengetahuan Indonesia (LIPI) terdapat 40\% masyarakat Indonesia yang menerima uang dari peserta pemilu 2019, serta 37\% masyarakat mengaku menerima dan tetap akan mempertimbangkan untuk memilih (Pahlevi \& Amrurobi, 2020). Sedangkan berdasarkan survey yang dilakukan oleh Komite Independen Sadar Pemilu (KISP) bahwa terdapat $42 \%$ masyarakat menanggap bahwa politik uang merupakan hal yang wajar dan biasa, sedangkan 30\% masyarakat menganggap prihatin dan 28\% menganggap sebagai masalah besar (Komite Independen Sadar Pemilu, 2019).

Dari beberapa hasil survey tersebut menyatakan bahwa memang pendidikan politik perlu dilakukan guna memberi perlawanan terhadap pratik politik uang. Di Daerah Istimewa Yogyakarta sendiri bentuk perlawanan masyarakat terhadap politik uang dimulai serentak melalui gerakan desa anti politik uang. Desa anti politik uang di Daerah Istimewa Yogyakarta tersebar di 4 Kabupaten dan 1 Kota Madya, berdasarkan data dari Badan Pengawas Pemilu (Bawaslu) Daerah Istimea Yogyakarta terdapat 34 desa yang mendeklarasikan diri sebagai DAPU (Pahlevi \& Amrurobi, 2020). Salah satu desa yang mendeklarasikan diri sebagai DAPU adalah Desa Temon Kulon Kecamatan Temon Kabupaten Kulon Progo. Adanya deklarasi tersebut diharapkan mampu memberikan dampak positif bagi masyarakat Desa Temon Kulon dan umumnya masyarakat Kabupaten Kulon Progo dalam melawan politik uang yang sudah marak 
terjadi di Indonesia, selain itu juga seabgai bagian dari bentuk kekecewaan masyarakat mengenai minimnya pelaksanaan pendidikan politik. Maka dari itu, hal ini snagat menarik untuk dikaji perihal bentuk kegaitan yang dilakukan dalam pembentukan desa anti politik uang di Desa Temon Kulon.

\section{Metode}

Pelaksanaan kegiatan pengabdian ini dilakukan di Desa Temon Kulon Kecamatan Temon Kabupaten Kulon Progo. Adapun tema pengabdian ini difokuskan pada pengembangan desa anti politik uang (Desa APU), mengingat pelaksanaan kegiatan pengabdian dilakukan pada saat persiapan Pemilu tahun 2019. Olah karena itu, untuk mencapai hasil yang maksimal perlu dilakukan ebebrapa kegiatan yang mendukung desa anti politik uang, adapun kegiatan yang dilaksanakan selama pengabdian adalah sebagai berikut:

1. Sosialisasi Bahaya Politik Uang dan Penggunaan Surat Suara, kegiatan ini dilakukan guna memberi pemahaman kepada masyarakat. Adapun sasaran dari kegaitan sosialisasi ini adalah masyarakat umum dan pemilih pemula. Hal ini tentu sangat membantu guna memberi pemahaman kepada masyarakat mengenai bahaya akan politik uang. Selain itu kegiatan sosialisasi ini juga bisa memberikan pengetahuan kepada masyarakat dan pemilih pemula di Desa Temon Kulon Kecamatan Temon Kabupaten Kulon Progo.

2. Pembuatan Spanduk dan Pojok Aduan Pemilu, merupakan salah satu sarana media yang dapat digunakan untuk mendukung kegiatan sosialisasi kepada masyarakat. Selain itu pembuatan alat bantu ini juga mempermudah kegiatan sosialisasi serta bisa memberikan pemahaman kepada masyarakat secara luas, karena alat bantu ini bisa dipasang disetiap sudut desa. Berikut adalah contoh pemasangan spanduk.

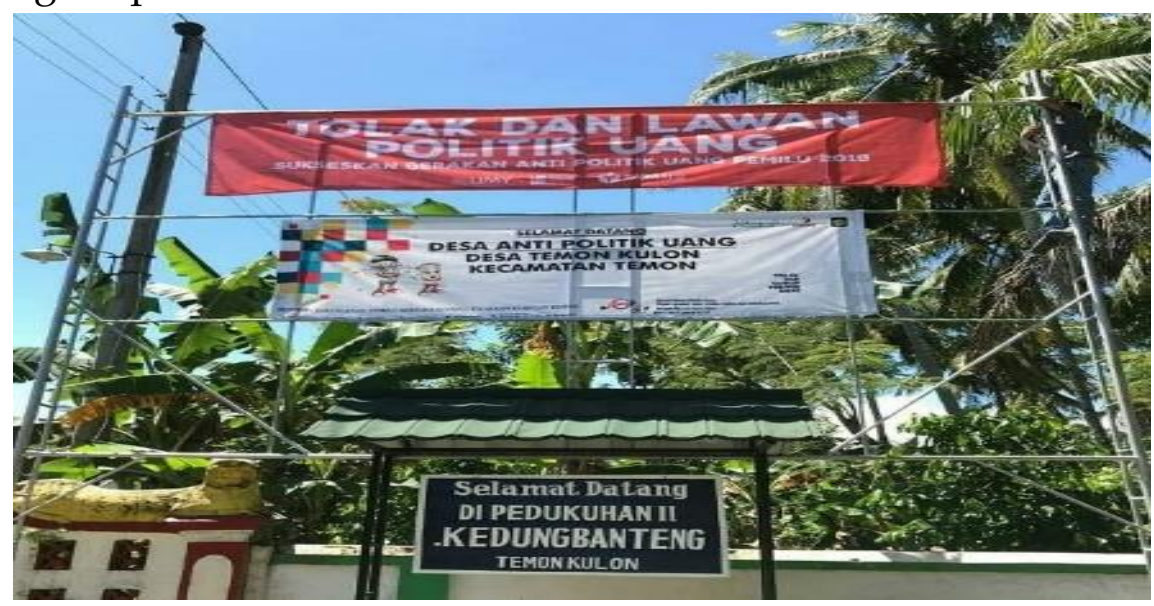

Sumber: dokumentasi tim KKN 007

Gambar. 1 Contoh Spanduk 


\section{Hasil dan Pembahasan}

Pengabdian masyarakat ini dilaksanakan kurang lebih selama 1 bulan atau 30 hari dengan komponen 15 hari sebelum dilaksanakan pemilihan umum dan 2 minggu setelah dilaksanakan pemilihan umum. Dimana pengabdian ini dilakukan di Desa Temon Kulon, Kecamatan Temon, Kabupaten Kulon Progo. Adapun tujuan dari pengabdian ini adalah untuk meminimalisir terjadinya praktik kecurangan dalam pelaksanaan pemilihan umum (Pemilu). Mengingat pemilu merupakan salah satu pesta rakyat terbesar atau hajatan negara Indonesia tersebesar yang dilaksanakan setiap 5 tahun sekali.

Adanya hajatan tersebut maka Desa Temon Kulon mempunyai inisiatif untuk mengembangkan desa anti politik uang (DAPU), sehingga pelaksanaan pemilu di desa tersebut bisa berjalan dengan baik. Selain itu tujuan desa dalam mengembangkan DAPU adalah meminimalisir terjadinya politik uang, dan sebagai saranan pendidikan politik bagi masyarakat Desa Temon Kulon. Dengan adanya kegiatan tersebut harapannya masyarakat bisa memahami mengenai bahaya money politik atau politik uang. Adapun kegiatan yang dilakukan di Desa Temon Kulon adalah sebagai berikut: sosialisasi dan pelatihan, pendidikan politik melalui alat peraga, pelepasan alat peraga kampanye (APK), dan pembuatan pojok aduan pemilu.

\section{Sosialisasi Bahaya Politik Uang dan Penggunaan Surat Suara}

Desa anti politik uang ini merupakan gagasan baru atau ide baru dalam mewujudkan demokrasi yang bersih. Gerakan desa anti politik uang (DAPU) muncul bukan karena tidak ada sebab, hal ini muncul dikarenakan maraknya praktik politik uang di setiap kegaitan pemilu, pemilukada maupun pemilukades. Hal inilah yang menimbulkan beberapa desa di Yogyakarta bergerak untuk melakukan dan membentuk gagasan desa anti politik uang (DAPU). Salah satu desa yang mendeklarasikan diri sebagai DAPU adalah Desa Temon Kulon Kecamatan Temon Kabupaten Kulon Progo.

Deklarasi DAPU ini diinisiasi oleh Pemerintah Desa dan masyarakat serta Panwaslu Kabupaten Kulon Progo. Hal ini dilakukan guna mewujudkan pemilu 2019 yang jujur di Kecamatan Temon, mengingat di Kecamatan Temon ada 3 Desa yang mendeklarasikan diri sebagai DAPU. Hal ini direspon sanat baik oleh Pemerintah Daerah maupun Komisi Pemilihan Umum Kabupaten Kulon Progo, Panwaslu serta masyarakat Kabupaten Kuon Progo. Dengan adanya DAPU ini harapannya tidak ada praktik politik uang di pemilu 2019, sehingga masyarakat bisa memilih pilihannya sesuai dengan hati nurani dan berdasarkan dari profil politik calon.

Dilakukannya deklarasi DAPU di beberapa desa di Daerah Istimewa Yogyakarta maka membuat Bawaslu Daerah Istimewa Yogyakarta melakukan kerjasama dengan Universitas Muhammadiyah Yogyakarta untuk melakukan beberapa kegaitan yang 
mendukung DAPU. Salah satu kegiatan yang dilakukan adalah menurukan KKN Khusus dengan skema Pemilu 2019, dimana KKN ini diturunkan disemua desa yang mendeklarasikan diri sebagai DAPU. Adapun kurun waktu pelaksanaan KKN skema khusus ini adalah 30 hari dengan rincian 15 hari sebelum pelaksanaan pemilu dan 15 hari setelah pelaksanaan pemilu. Salah satu desa yang ditempati KKN skema khusus ini adalah Desa Temon Kulon Kecamatan Temon Kabupaten Kulon Progo.

Selama kegaitan pengabdian masyarakat ini ada beberapa kegaitan yang dilakukan salah satunya adalah sosialisasi. Dimana kegiatan sosialisasi ini lebih difokuskan pada tata cara pencoblosan surat suara, dan bahaya politik uang. Mengingat pemilu 2019 merupakan pemilu model baru dengan pelaksanaan pemilu dilakukan secara serentak, maka dari itu perlu adanya sosialisasi secara intens kepada masyarakat mengenai tata cara pencoblosan. Selama pelaksanaan sosialisasi tata cara pencoblosan tim pengabdian bekerjasama dengan Pemerintah Desa Temon Kulon serta Panwaslu Kabupaten Kulon Progo maupun Akademisi serta LSM yang bergerak dibidang pemilu atau demokrasi. Selain itu juga dilakukan koordinasi dengan Panwalu Kabupaten Kulon Progo, khususnya berkoordinasi mengenai materi yang akan diberikan kepada masyarkat maupun koordinasi dalam penjadwalan sosialisasi setiap desa, sehingga pelaksanaan sosialisasi berjalan dengan lancar dan dipantau secara langsung oleh Panwaslu Kabupaten Kulon Progo dan Pemerintah Desa.

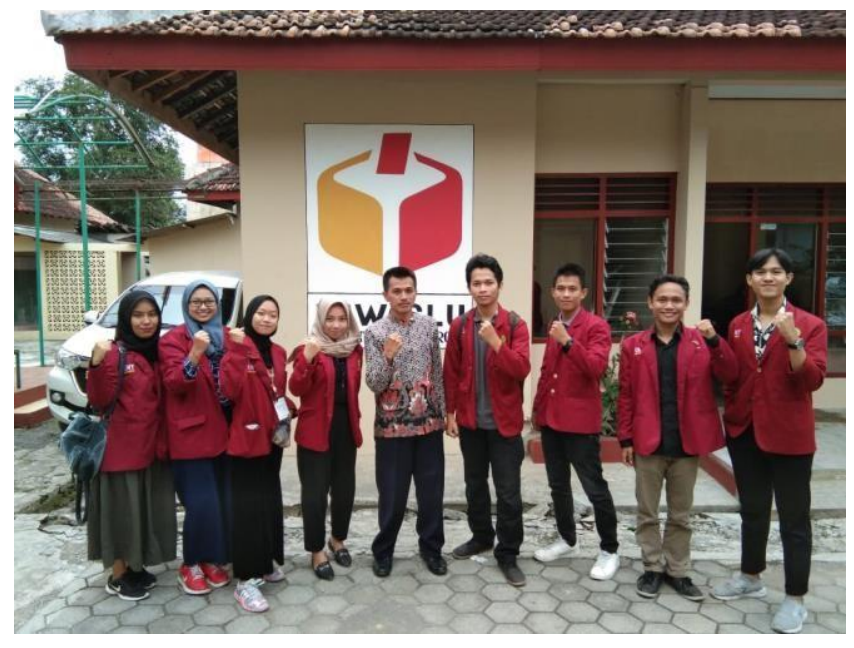

Sumber: dokumentasi tim KKN kelompok 007

Gambar 2. Koordinasi dengan Panwaslu Kabupaten Kulon Progo

Kegaitan sosialisasi ini diikuti oleh masyarakat secara antusias, sehingga perlu dilakukan penjadwalan sosialisasi setiap padukuhan. Adapun sasaran dari sosialisasi ini adalah masyarakat Temon Kulon terutama yang mempunyai hak suara dan hak pilih. Selain itu yang tidak kalah pentingnya sasaran dari sosialisasi ini adalah pemilh pemula, mengingat pemilih pemula orang yang pertama kali mempunyai hak pilih dan hak suara. Sehingga perlu diberi pengetahuan mengenai tata cara pemilihan suara 
serta bahaya politik uang. Berikut adalah jadwal sosialisasi pengabdian di Desa Temon Kulon Kecamatan Temon Kabupaten Kulon Progo.

Tabel. 1 Jadwal Sosialisasi

\begin{tabular}{|c|l|l|}
\hline No & \multicolumn{1}{|c|}{ Tempat/Padukuhan } & \multicolumn{1}{c|}{ Hari/Tanggal } \\
\hline $\mathbf{1}$ & Padukuhan Kaliwangan Kidul & Sabtu/ 4 April 2019 \\
\hline $\mathbf{2}$ & Padukuhan Kedung Banteng & Senin/ 6 April 2019 \\
\hline $\mathbf{3}$ & Padukuhan Kaligondang & Rabu/ 8 April 2019 \\
\hline $\mathbf{4}$ & Padukuhan Seling & Jumat/ 10 April 2019 \\
\hline $\mathbf{5}$ & Padukuhan Kaliwangan Lor & Minggu/ 12 April 2019 \\
\hline
\end{tabular}

Sumber: dokumentasi tim KKN kelompok 007

Selain diikuti oleh masyarakat secara antusias pelaksanaan sosialisasi ini juga didukung oleh Pemerintah Desa Temon Kulon serta Panwaslu Kabupaten. Hal ini dapat dilihat dari setiap pelaksanaan acara selalu didampingi oleh aparat desa beserta babinsa dan bainkamtibmas serta didampingi minimal 1 orang dari Panwaslu Kabupaten Kulon Progo. Hal ini dikarenakan sangat pentingnya acara sehingga perlu ada pendampingan secara langsung oleh pemerintah desa maupun Panwaslu. Pendampingan disetiap acara sosialisasi merupakan bukti bahwa adanya keseriusan dari pemerintah desa maupun Panwaslu Kabupaten dalam mewujudkan pemilu yang adil dan bersih.

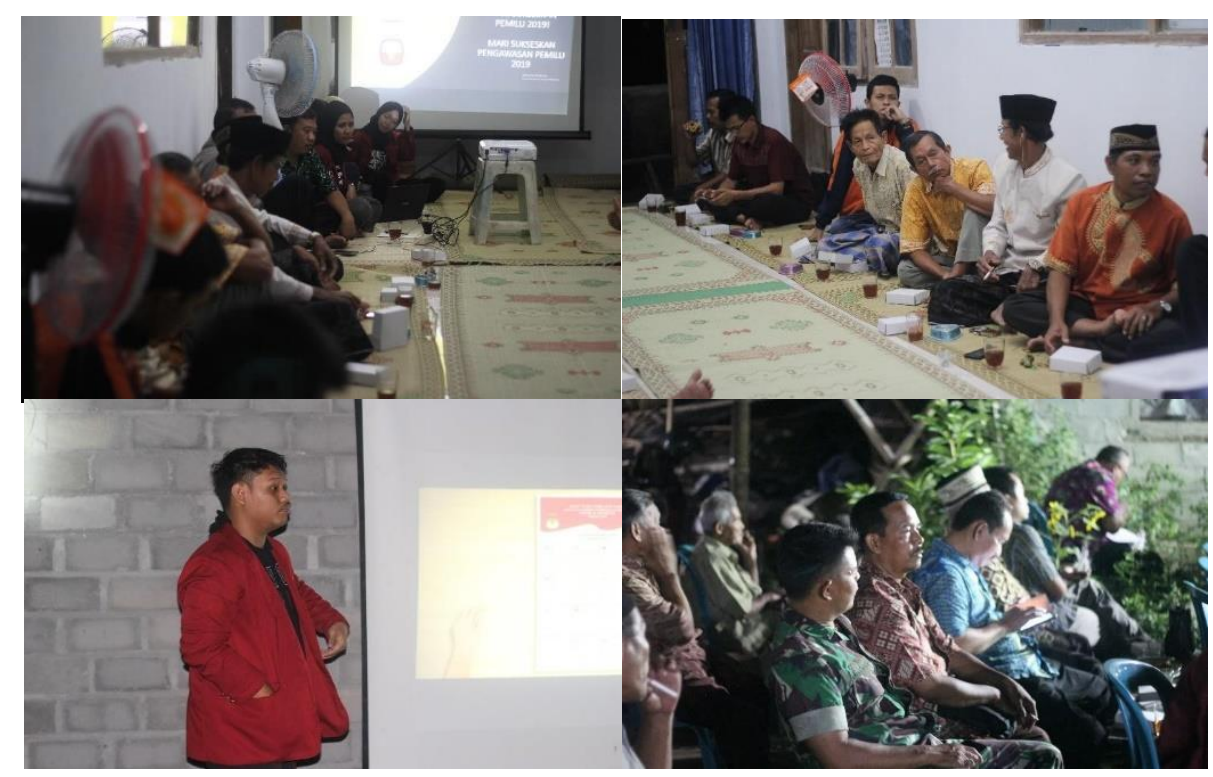

Sumber: dokumentasi tim KKN 007

Gambar 3. Kegiatan Sosialisasi Tata Cara Pencoblosan dan Bahaya Politik Uang

Kegiatan ini dilakukan dengan harapan masyarakat Temon Kulon bisa memahami akan bahaya politik uang dan konsekuensi politik uang pada pemilu. Selain itu kegiatan ini juga melaksanakan sosialisasi tentang tata cara pencoblosan surat suara. Karena pada pelaksanaan pemilu kali ini sangat berbeda dengan pemilu sebelumnya. 
Dimana pemilu tahun 2019 dilaksanakan secara serentak dan memilih presiden maupun wakil rakyat baik daerah, provinsi maupun pusat secara bersamaan. Maka dari itu, perlu adanya kegaitan sosialisasi kepada masyarakat mengenai tata cara pemilihan.

Berdasarkan kegiatan yang telah dilaksanakan banyak sekali manfaat yang dirasakan oleh masyarakat, diantaranya adalah tata cara pencoblosan surat suara. Yang mana masyarakat sangat terbantu dengan adanya sosialisasi ini karena metode pencoblosan surat suara bisa dipraktikkan sebelum adanya pemilihan umum. Selain itu masyarakat juga bisa memahami akan bahaya politik uang, karena dengan adanya sosialisasi ini banyak sekali masyarakat yang bisa memahami dampak dan bahaya laten dari politik uang terutama untuk lima tahun kedepan. Sehingga dengan adanya sosialisasi ini banyak sekali manfaat yang dirasakan oleh masyarakat Desa Temon Kulon Kecamatan Temon Kabupaten Kulon Progo.

\section{Pembuatan Spanduk dan Pojok Aduan Pemilu}

Selain kegiatan sosialisasi maka kegiatan lain yang dilakukan adalah mengenai pembuatan spanduk dan pojok aduan pemilu. Hal ini pelru dilakukan guna mengakomodasi masukan serta keluhan masyarakat terkait pemilu 2019. Pembuatan spanduk akan lebih banyak difokuskan pada tulisan tentang ajakan kepada masyarkaat untuk melakukan perlawanan terhadap praktik politik uang. Dimana dengan tulisan yang bernada ajakan tersebut harapannya masyarakat Desa Temon Kulon bisa sadar serta bisa menolak praktik-praktik politik uang. Mengingat praktik politik uang sudah marak sekali dilakukan di Indonesia dengan berbagai macam cara.

Politik uang merupakan bagian dari kecurangan dalam pelaksanaan pemilihan umum maupun pemilihan kepala daerah, oleh karena itu perlu dihindari guna mewujudkan pemilu yang berintegritas dan adil. Karena dengan adanya politik uang maka masyarakat akan menerima konsekuensi atau akibatnya, dimana akan banhyak sekali terjadi praktik korupsi dan lain sebagainya. Maka dari itu untuk menghindari politik uang Desa Temon Kulon mendeklarasikan diri sebagai DAPU. Sehingga dengan dideklaraasikan sebagai DAPU harapannya bisa meminimalisir terjadinya politik uang di desa tersebut.

Adapun spanduk yang bertuliskan perlawanan terhadap politik uang dipasang diberbagai tempat yang sangat strategis, sehingga masyarakat bisa melihat secara jelas. Tujuan dari pemasangan ini secara tidak langsung untuk menunjukkan kepada masyarakat bahwa Desa Temon Kulon melakukan perlawanan terhadap politik uang dengan sangat serius. Perlawanan politik uang yang dilakukan di Desa Temon Kulon ini diawali dengan adanya sosialisasi mengenai bahaya politik uang sampai dengan pemasangan spanduk atau baliho-baliho disetiap sudut desa. 


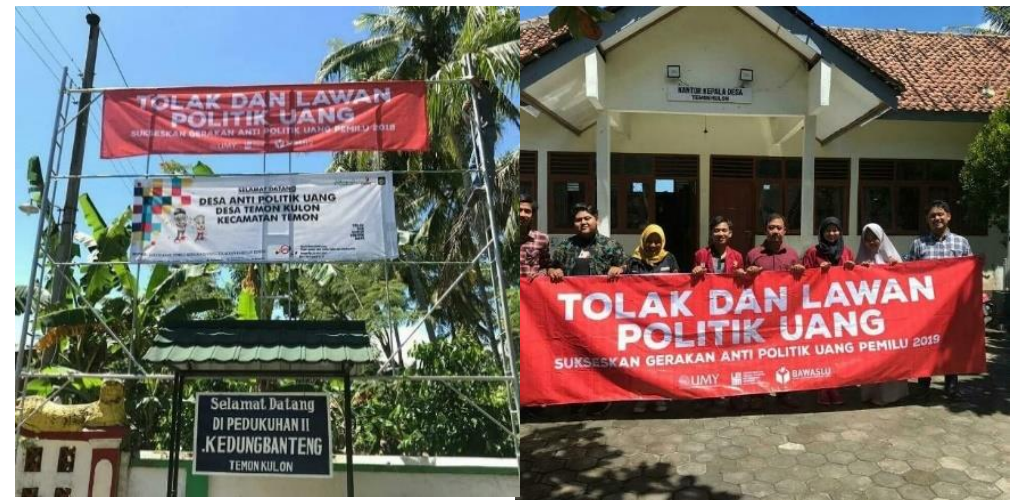

Sumber: dokumentasi tim KKN 007

Gambar 4. Pemasangan Spanduk Penolakan Praktik Politik Uang

Pemasangan tersebut merupakan bukti bahwa adanya keseriusan dari pemerintah desa untuk melawan praktik politik uang dalam pelaksanaan pemilu. Selain itu juga sebagai bukti bahwa pemerintah desa ingin mewujudkan pemilu yang berintegritas dan adil di Desa Temon. Dengan adanya gerakan ini maka harapan dari pemerintah desa adalah pemilu di Desa Temon bisa berjalan dengan baik serta masyarakat bisa memahami akan bahaya dan resiko jika terjadi politik uang. Selain itu harapannya adalah masyarakat Desa Temon Kulon memilih dan menggunakan hak suaranya sesuai dengan hati nurani bukan karena uang atau sembako dan yang lain sebagainya.

Selain melakukan pemasangan spanduk yang mengajak untuk melawan praktik politik uang, maka kegiatan lain yang dilakukan adalah membuat pojok aduan. Pojok aduan ini bertujuan untuk mewadahi dan menampung keluh kesah maupun aspirasi dan temuan masyarakat mengenai pemilu 2019. Pojok aduan ini dibuka setiap hari selama kurang lebih 15 hari, dengan komposisi 1 minggu sebelum pelaksanaan pemilu dan 1 minggu setelah pelaksanaan pemilu. Pojok aduan yang dibuat ini akan menampung aduan masyarakat terhadap pelaksanaan pemilu 2019 di Desa Temon Kulon.

Masyarakat bisa melakukan pelaporan kepada pojok aduan dengan melalui SMS pada nomor interaktif yang telah dipasang. Selain itu masyarakat juga bisa melakukan atau melaporkan secara langsung dengan cara datang ke Balai Desa Temon Kulon setiap hari. Ketika ada laporan dari masyarakat mengenai pemilu maka akan secara langsung dilaporkan kepada Panwascam dan Panwaslu Kabupaten Kulon Progo. Sehingga aduan masyarakat mengenai pemilu segera teratasi dengan baik. Pojok aduan ini snagat efektif untuk membantu mewujudkan pemilu yang berintegritas dan adil. 


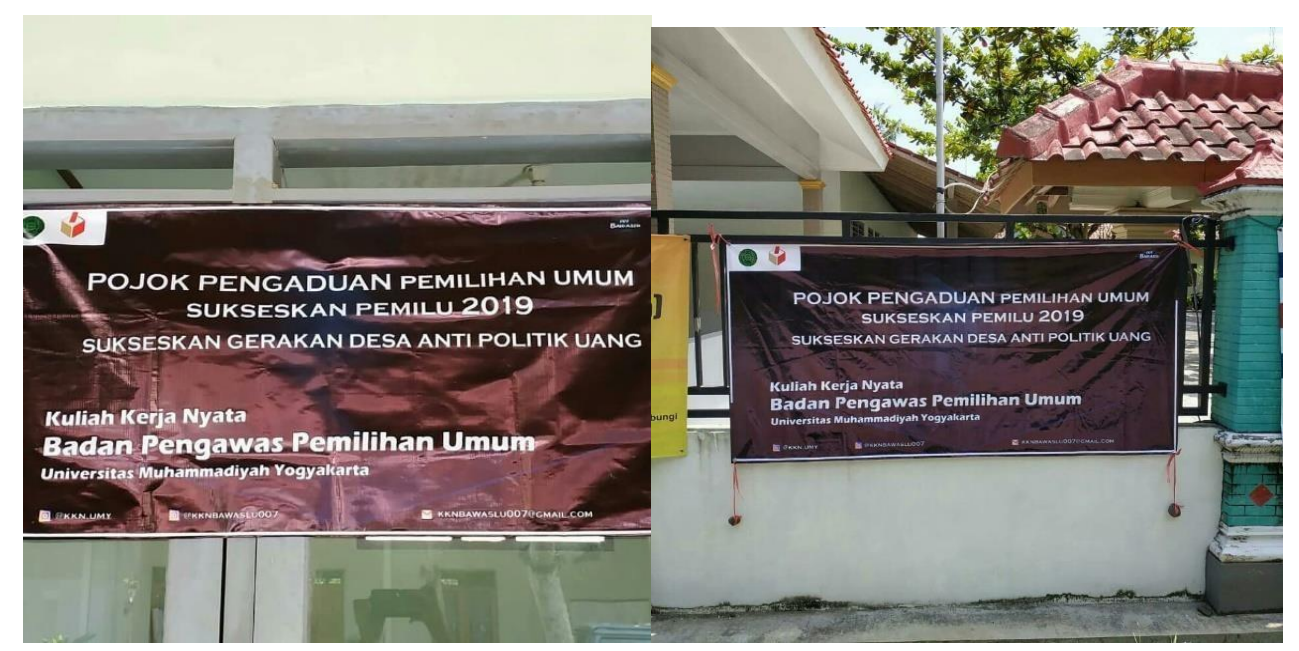

Sumber: dokumentasi tim KKN 007

Gambar 5. Pojok Aduan Pemilu

\section{Simpulan dan Rekomendasi}

Berdasarkan hasil pelaksanaan pengabdian tersebut maka dapat disimpulkan bahwa, desa anti politik uang yang dikembangkan dan dibentuk di Desa Temon Kulon mempunyai beberapa kegaitan. Salah satunya adalah Sosialisasi Bahaya Politik Uang dan Penggunaan Surat Suara dan Pembuatan Spanduk dan Pojok Aduan Pemilu. Kedua kegiatan tersebut diikuti oleh masyarakat dengan snagat antusias, selain itu kegiatan ini juga didukung oleh Pemerintah Desa Temon Kulon serta Panwaslu Kabupaten Kulon Progo. Mengingat pentingnya hal ini maka langkah-langkah yang dilakukan untuk mewujudkan desa anti politik uang adalah dengan melaksanakan sosialisasi secara langsung terkait bahaya politik uang. Selain itu sosialisasi juga membahas tentang tata cara pencoblosan surat suara, mengingat pemilu 2019 merupakan pemilu pertama kali yang diadakan secara serentak, baik Presiden, DPR, DPD, maupun DPRD. Sehingga perlu dilakukan sosialisasi supaya masyarakat paham dan tau mengenai surat suara yang akan dipilih.

Selain sosialisasi bentuk kegiatan lain yang dilakukan adalah membuat dan memasang spanduk dengan tulisan atau ajakan untuk menolak segala bentuk politik uang. Bentuk perlawanan ini dilakukan secara serentak di berbagai desa di Daerah Istimewa Yogyakarta. Mengingat hal ini merupakan hal yang sangat penting dan vital, maka perlu dilakukan deklarasi maupun perlawanan secara massif. Spandukspanduk tersebut dipasang di setiap pojok jalan, sehingga masyarakat bisa mengenatahui komitmen dan keseriusan pemerintah desa. Selain itu juga dibuatkan pojok aduan yang mempunyai manfaat untuk menerima aduan dari masyarakat. Bentuk aduan yang bisa diterima adalah bentuk aduan seputar pemilu 2019, baik mengenai politik uang, sampai dengan praktik kecurangan dalam penghitungan suara. Mengingat pojok aduan ini akan diintegrasikan dengan Panwaslu Kabupaten 
sehingga ketika ada aduan yang masuk maka harus secara tepat direspon oleh masyarakat.

Adanya kegiatan ini snagatlah efektif bagi masyarakat di Desa Temon Kulon Kecamatan Temon Kabupaten Kulon Progo. Hal ini tentu dirasakan oleh masyarakat salah satunya masyarakat bisa memahami dan mengerti akan bahaya politik uang serta tata cara pemilihan umum. Tentu masyarakat secara luas bisa merasakan kegunaan atau manfaat kegiatan ini karena masyarakat bisa mempraktekkan secara langsung tata cara pencoblosan surat suara. Selain itu masyarakat juga bisa merasakan secara langsung dampak dari sosialisasi diantaranya banyak masyarakat yang sudah memahami bahaya akan politik uang untuk lima tahun kedepan.

\section{Penghargaan}

Pada pelaksanaan kegiatan ini kami ucapkan terima kasih banyak kepada tim KKN 007 yang telah banyak membantu pada teknis pengabdian. Selain itu kami ucapkan terima kasih juga kepada Universitas Muhammadiyah Yogyakarta dan LP3M yang telah menerjunkan mahasiswa untuk pelaksanaan KKN. Kami ucapkan terima kasih juga kepada Panwaslu Kabupaten Kulon Progo dan Pemerintah Desa Temon Kulon sebagai tempat pelaksanaan pengabdian.

\section{Daftar Pustaka}

Abhipraya, F.A; Sadayi, D.P; \& Putri, F.A. (2020). Peran Komite Independen Sadar Pemilu (KISP) sebagai LSM Kepemiluan dalam Melawan Praktik Politik Uang. POLITICON: Jurnal Ilmu Politik, 2(2).

Ananingsih, S.W. (2016). Tantangan dalam Penanganan Dugaan Praktik Politik Uang pada Pilkada Serentak Tahun 2017. Masalah-Masalah Hukum, 45(1).

Aspinall, E; and Sukmajati, M. (2015). Politik Uang di Indonesia Patronase dan Klientelisme pada Pemilu Legislatif 2014. Yogyakarta: PolGov.

Asmawi. M; Amiludin; \& Sofwan, E. (2021). Strategi Badan Pengawas Pemilu Kabupaten Serang dalam Pencegahan Praktik Politik Uang. Indonesia Journal of Law and Policy Studies, 2(1).

Fitriyah. (2012). Fenomena Politik Uand dalam Pemilukada. POLITIKA: Jurnal Ilmu Politik, 3(1).

Komite Independen Sadar Pemilu. (2019). Pemilih Milenial dan Konsistensi Politik Elektoral (Evaluasi dan Hasil Penelitian Komite Independen Sadar Pemilu dalam Pemilu Serentak 2019). Yogyakarta: Rua Aksara.

Marsudi; Rosalina, K.E; and Sunarso. (2019). Revitalisasi Pendidikan Politik melalui Pembentukan Kampung Anti Money Politik. JPPUMA: Jurnal Ilmu Pemerintahan dan Sosial Politik UMA, 7(2). 
Muhtadi, B. (2013). Politik Uang dan Dinamika Elektoral di Indonesia: Sebuah Kajian Awal Interaksi antara "Party-ID" dan Patron-Klien. Jurnal Penelitian Politik, 10(1).

Pahlevi, M.E.T; and Amrurobi, A.A. (2020). Pendidikan Politik dalam Pencegahan Politik Uang Melalui Gerakan Masyarakat Desa. Integritas: Jurnal Antikorupsi, 6(1).

Satia, H. (2019). Politik Hukum Tidak Pidana Politik Uang dalam pemilihan Umum di Indonesia. Integritas: Jurnal Antikorupsi, 5(1).

Sjafrina, A.G.P. (2019). Dampak Politik Uang terhadap Mahalnya Biaya Pemenangan Pemilu dan Korupsi Politik. Integritas: Jurnal Antikorupsi, 5(1).

Suprianto, L.O; Arsyad, M; and Tawulo, M.A. (2020). Persepsi Masyarakat terhadap Politik Uang pada Pilkada Serentak (Studi di Desa Ronta Kecamatan Bonegunu Kabupaten Buton Utara). Neo Societal, 2(1). 